PRINT ISSN 1119-8362

Electronic ISSN 1119-8362
Full-text Available Online at

https://www.ajol.info/index.php/jasem

http://ww.bioline.org.br/ja
J. Appl. Sci. Environ. Manage.

Vol. 25 (3)397-400 March 2021

\title{
Isolation and NMR Characterization of Ursane-Type Triterpenoid from the Leaves of Peperomia pellucida
}

\author{
IBE-DIALA, JC;* IGWE, OU; FRIDAY, C; AKWADA, UC \\ Department of Chemistry, Michael Okpara University of Agriculture, Umudike, P.M.B. 7267 Umuahia, Abia State, Nigeria \\ *Corresponding Author Email: julietibe91@ gmail.com; Tel: +2349036595420
}

\begin{abstract}
Peperomia pellucida is a member of the Piperaceae family. Extraction of plant material was carried out by Soxhlet extraction method using hexane and ethylacetate as solvents respectively. The extract was concentrated using a rotary evaporator, followed by isolation and purification using column and thin layer chromatographic techniques. Fraction $\mathrm{C} 20$ showed a clearly defined single spot with $\mathrm{R}_{\mathrm{f}}$ value of 0.51 . Using ${ }^{1} \mathrm{H}-$ NMR, ${ }^{13} \mathrm{C}$-DEPT, COSY, HSQC and HMBC and by comparison with literature values, the structure of the compound was established as an Ursane-type triterpenoid. The use of P. pellucida in ethnomedicine for the treatment of various ailments could be attributed to the Ursane-type triterpenoid and other bioactive chemical compounds present in the plant.
\end{abstract}

\section{DOI: https://dx.doi.org/10.4314/jasem.v25i3.13}

Copyright: Copyright (C) 2021 Ibe-Diala et al. This is an open access article distributed under the Creative Commons Attribution License (CCL), which permits unrestricted use, distribution, and reproduction in any medium, provided the original work is properly cited.

Dates: Received: 12 December 2020; Revised: 26 January 2021; Accepted: 12 February 2021

Keywords: Peperomia pellucida, extraction, isolation, chromatographic techniques, ursane-type triterpenoid

Plant derived substances have recently become of great interest owing to their versatile applications. Medicinal plants are the richest bio-resources of drugs of traditional medicines, modern medicines, pharmaceutical intermediates and chemical entities for drug synthesis. The use of medicinal plants in the treatment and management of various ailments has increased significantly such that a greater number of people in Nigeria now rely on plant based medicines as their source of primary healthcare especially, in rural communities, (Karunamoorthi et al., 2013). Peperomia pellucida is a member of the Piperaceae family. The common names include pepper elder, shining bush plant, and English cow-foot. It is an edible plant native to South America and has been widely grown in many countries in the world, including West African countries. The plant grows in shaded and damp hard surfaces and is very common during rainy season.

It is characterized by succulent stems, freshly and heart-shaped leaves and tiny dots like seeds attached to the fruiting spikes. When crushed, it has a mustardlike odour. $P$. pellucida is one of the known medicinal plants used in various parts of the world for the treatment of various diseases and infections such as rheumatism, diarrhea, dysentery, convulsion, epilepsy, paralysis, tumour, joint and abdominal pain, cough, cold, fever, asthma, boils, acne, renal disorders, fatique, headache, wound, vaginal and kidney infections (Coe and Anderson, 1999; Khan and Omoloso, (2002). In Nigeria, the whole plant is used in the treatment of measles, convulsion, hypertension and bone fracture (Chukwuma et al., 2015). In India, it is used for pimples, white spots, wounds and stomach problems (Das et al., 2014; Kalita et al., 2015). It is used in Brazil for the treatment of hemorrhoid pain and kidney infections, while the aerial parts are used in Indonesia for stomachache, dizziness and headache (Santos et al., 2014; Waty et al., 2017). In Africa, it is used as a condiment, and eaten as a spicy leafy vegetable. The pharmacological activities of $P$. pellucida leaves such as hypotensive, anti-inflammatory, antioxidant, antipyretic, gastroprotective, antidiabetic and antibacterial activities have been reported (Khan and Omoloso, 2002; Nwokocha et al., 2012; Humzah et al., 2012).

Previous researchers isolated a good number of compounds from $P$. pellucida. Manalo et al., (1983) isolated 2, 4, 5-trimethoxy styrene, campesterol, stigmasterol, and $\beta$-sitosterol. Xu et al., (2006) isolated thirteen compounds, with five being novel. Khan et al., (2010) isolated patuloside A (3- $\beta$ Dglucopyranosyloxy- $1, \quad 5, \quad 6$-trihydroxy-9Hxanthene-9-one). In the present research, we report the isolation and NMR characterization of an ursane-type triterpenoid from the leaves of $P$. pellucida. This is the first report of the isolation of an ursane-type triterpenoid from the leaves of $P$. pellucida. 


\section{MATERIALS AND METHODS}

Sample Collection and Preparation: P. pellucida leaves were harvested from Umunomo Ihitteafokwu in Ahiazu Mbaise Local Government Area of Imo State, Nigeria. The plant material was identified and authenticated at the Taxonomy Unit, Forestry Department, Micheal Okpara University of Agriculture Umudike, Nigeria. The leaves were handpicked and air dried for 30 days at room temperature. The dried leaves were milled to fine powder using a laboratory mill.

Extraction of Plant Chemicals and Compound Isolation: Extraction of plant material was carried out by Soxhlet extraction method using hexane and ethylacetate as solvents respectively. The extract was concentrated using a rotary evaporator at room temperature and left on the laboratory bench for 2 days. The column was washed with acetone and rinsed with n-hexane. The column was prepared by packing a glass column $(2.5 \mathrm{~cm}$ by $80 \mathrm{~cm})$ with slurry of silica gel $(60.2 \mathrm{~g})$ in $200 \mathrm{ml}$ of $\mathrm{n}$-hexane. The slurry was introduced in one smooth flow and the solvent drained off to the top of the column bed. A dry free flowing mixture of plant extract was introduced onto the silica bed. $100 \mathrm{ml}$ of $\mathrm{n}$-hexane was used to wash down sides of the column and also to fill it up. Solvent mixture of n-hexane and ethylacetate $(90: 10 \mathrm{ml})$ was introduced and collection of fractions in well labeled vials began just before the plant material travelled to the column neck. This continued for the following solvent mixtures - 80:20, 70:30, 60:40, 50:50, 40:60, 30:70, 20:80, 10:90, 0:100. Thereafter, a more polar solvent, methanol $(100 \mathrm{ml})$ was used to elute the more polar components from the column. A total of 57 vials were collected. Each fraction was spotted using a capillary tube on a precoated TLC plate and developed in a solvent mixture of 3:7 ml (ethylacetate: hexane). Fraction C20 gave a single spot on TLC with $R_{f}$ value of 0.51. It was packaged in a vial and sent to University of Strathclyde, Glasgow, Scotland, for spectral analysis.

\section{RESULTS AND DISCUSSION}

The ${ }^{1} \mathrm{H}-\mathrm{NMR}$ for fraction C20 (Tables 1 and 2) showed the presence of four olefinic protons at 5.70 ppm (H-12, d) J (1.36), 5.18 ppm (H-15, dd) J (15.20 $\mathrm{Hz}, 8.58 \mathrm{~Hz}), 5.04$ ppm (H-16, dd) J (15.14 Hz, 8.68 $\mathrm{Hz})$ and $4.52 \mathrm{ppm}(\mathrm{H}-30, \mathrm{~d}) \mathrm{J}(1.64,1.72)$. The signals at $3.55 \mathrm{ppm}(\mathrm{H}-3, \mathrm{tt}) \mathrm{J}(11.09,4.63)$ are features of a sterol moiety. The signals at $1.03 \mathrm{ppm}(\mathrm{H}-1)$ and 1.87 ppm (H-22 ddt) $\mathrm{J}(13.47,6.09,3.41)$ are characteristic of methylene protons. The other signal at $0.83 \mathrm{ppm}(\mathrm{H}-$ $24)$ is a methyl proton. The ${ }^{1} \mathrm{H}-{ }^{1} \mathrm{H}-\mathrm{COSY}$ showed correlations at $5.04 \mathrm{ppm}(\mathrm{H}-16, \mathrm{dd}), 5.18 \mathrm{ppm}(\mathrm{H}-15$, dd), $5.07 \mathrm{ppm}(\mathrm{H}-12, \mathrm{~d})$ and 4.52ppm (H-30 s) characteristics of vinylic protons. ${ }^{1} \mathrm{H}-{ }^{1} \mathrm{H}$ coupling signals were also observed at $3.55 \mathrm{ppm}$ (H-3.td, $\mathrm{J}=11.09,4.63 \mathrm{~Hz}$ ) confirming the presence of a sterol moiety. The signals at $1.03 \mathrm{ppm}(\mathrm{H}-1 \mathrm{~m})$ and $1.87 \mathrm{ppm}$ (H-22 ddt) $\mathrm{J}(13.47,6.09,3.41)$ are characteristics of a methylene proton.

\begin{tabular}{|c|c|c|}
\hline $\begin{array}{l}\text { Position of } \\
\text { hydrogen }\end{array}$ & $\begin{array}{l}\text { Chemical } \\
\text { shift (ppm) }\end{array}$ & $\begin{array}{l}\text { Assignment } \\
\text { (type of proton) }\end{array}$ \\
\hline 1 & 1.03 & $-\mathrm{CH}_{2}$ \\
\hline 2 & 1.67 & $-\mathrm{CH}_{2}$ \\
\hline 3 & 3.55 & $-\mathrm{CH}-\mathrm{OH}$ \\
\hline 4 & - & - \\
\hline 5 & 0.86 & $-\mathrm{CH}$ \\
\hline 6 & 5.38 & $-\mathrm{CH}_{2}$ \\
\hline 7 & 1.84 & $-\mathrm{CH}_{1}$ \\
\hline 8 & - & - \\
\hline 9 & 1.55 & $-\mathrm{CH}$ \\
\hline 10 & - & - \\
\hline 11 & 1.85 & $-\mathrm{CH}_{2}$ \\
\hline 12 & 5.70 & $=\mathrm{CH}$ \\
\hline 13 & - & - \\
\hline 14 & - & - \\
\hline 15 & 5.18 & $=\mathrm{CH}$ \\
\hline 16 & 5.04 & $=\mathrm{CH}$ \\
\hline 17 & - & - \\
\hline 18 & 1.67 & $-\mathrm{CH}$ \\
\hline 19 & 1.01 & $-\mathrm{CH}$ \\
\hline 20 & 1.41 & $-\mathrm{CH}$ \\
\hline 21 & 1.52 & $-\mathrm{CH}_{1}$ \\
\hline 22 & 1.87 & $-\mathrm{CH}_{1}$ \\
\hline 23 & 0.82 & $-\mathrm{CH}_{1}$ \\
\hline 24 & 0.83 & $-\mathrm{CH}_{3}$ \\
\hline 25 & 0.84 & $-\mathrm{CH}_{3}$ \\
\hline 26 & 0.85 & $-\mathrm{CH}_{3}$ \\
\hline 27 & 1.01 & $-\mathrm{CH}_{3}$ \\
\hline 28 & 1.25 & $-\mathrm{CH}_{3}$ \\
\hline 29 & 0.76 & $-\mathrm{CH}_{3}$ \\
\hline 30 & 4.52 & $-\mathrm{CH}_{3}$ \\
\hline
\end{tabular}

The DEPT-135 spectrum showed the presence $7-\mathrm{CH}_{3}$, $8-\mathrm{CH}_{2}$ and $9-\mathrm{CH}$ carbons. The signals at $138.33 \mathrm{ppm}$ (C-16), $129.30 \mathrm{ppm}(\mathrm{C}-15), 114.33 \mathrm{ppm}(\mathrm{C}-12)$ and $106.37 \mathrm{ppm}(\mathrm{C}-30)$ are characteristics of the four vinylic carbons of the sterol moiety. Also, the signals at $71.84 \mathrm{ppm}$ correspond to the methine carbon of the sterol moiety (C-3). Moreso, signals were also observed at $37.27 \mathrm{ppm}(\mathrm{C}-22)$ and $40.50 \mathrm{ppm}(\mathrm{C}-1)$ characteristics of methylene carbons.

The ${ }^{1} \mathrm{H}-{ }^{13} \mathrm{C}$ HSQC spectra showed correlations between the carbon atom at (C-12) at $114.33 \mathrm{ppm}$ and the proton $(\mathrm{H}-12)$ at $5.70 \mathrm{ppm}, \mathrm{C}-15$ at $129.30 \mathrm{ppm}$ and $(\mathrm{H}-15)$ at $5.18 \mathrm{ppm}$ and the carbon atom $(\mathrm{C}-16)$ at $138.33 \mathrm{ppm}$ and the proton $(\mathrm{H}-16)$ at $5.04 \mathrm{ppm}$ as well as between the carbon atom $(\mathrm{C}-3)$ at $71.84 \mathrm{ppm}$ and the proton $(\mathrm{H}-3)$ at $3.55 \mathrm{ppm}$. The signals at $40.50(\mathrm{C}$ $1)$ and $37.27(\mathrm{C}-22)$ were assigned to the methylene carbons at protons 1 and 22 respectively. 
Also, ${ }^{1} \mathrm{H}-{ }^{13} \mathrm{C}$ HSQC showed single bond coupling between carbon atoms (C-24) at $29.18 \mathrm{ppm}$ and the proton $(\mathrm{H}-24)$ at $0.83 \mathrm{ppm}$ as well as the carbon atom $(\mathrm{C}-25)$ at $28.26 \mathrm{ppm}$ and the proton $(\mathrm{H}-25)$ at $0.84 \mathrm{ppm}$. The analysis of the ${ }^{1} \mathrm{H},{ }^{1} \mathrm{H}-{ }^{1} \mathrm{H}$ COSY, DEPT and HSQC were in agreement with reported literatures for an ursane-type triterpenoid (Pranab et al., 2012; Hayat et al., 2005; Yan-Li et al., 2013).

\begin{tabular}{|c|c|c|}
\hline $\begin{array}{l}\text { Position of } \\
\text { carbon atom }\end{array}$ & $\begin{array}{l}\text { Chemical } \\
\text { ghift (ppm) }\end{array}$ & Assignment \\
\hline 1 & 40.50 & $-\mathrm{CH}_{2}$ \\
\hline 2 & 29.71 & $-\mathrm{CH}_{2}$ \\
\hline 3 & 71.84 & $-\mathrm{CH}-\mathrm{OH}$ \\
\hline 4 & - & - \\
\hline 5 & 56.79 & $-\mathrm{CH}$ \\
\hline 6 & 18.80 & $-\mathrm{CH}_{2}$ \\
\hline 7 & 31.90 & $-\mathrm{CH}_{2}$ \\
\hline 8 & - & - \\
\hline 9 & 50.18 & $-\mathrm{CH}$ \\
\hline 10 & - & - \\
\hline 11 & 24.32 & $-\mathrm{CH}_{2}$ \\
\hline 12 & 114.33 & $=\mathrm{CH}$ \\
\hline 13 & - & - \\
\hline 14 & - & - \\
\hline 15 & 129.30 & $=\mathrm{CH}$ \\
\hline 16 & 138.33 & $=\mathrm{CH}$ \\
\hline 17 & - & - \\
\hline 18 & 55.52 & $-\mathrm{CH}$ \\
\hline 19 & 56.08 & $-\mathrm{CH}$ \\
\hline 20 & 56.79 & $-\mathrm{CH}$ \\
\hline 21 & 31.68 & $-\mathrm{CH}_{2}$ \\
\hline 22 & 37.27 & $-\mathrm{CH}_{2}$ \\
\hline 23 & 21.10 & $-\mathrm{CH}_{2}$ \\
\hline 24 & 29.18 & $-\mathrm{CH}$ \\
\hline 25 & 28.26 & $-\mathrm{CH}_{\mathrm{s}}$ \\
\hline 26 & 19.41 & $-\mathrm{CH}$ \\
\hline 27 & 26.11 & $-\mathrm{CHa}$ \\
\hline 28 & 19.41 & $-\mathrm{CH}$ \\
\hline 29 & 19.05 & $-\mathrm{CH}$ \\
\hline 30 & 106.37 & $=\mathrm{CH}_{1}$ \\
\hline
\end{tabular}

Thus confirming that $\mathrm{C} 20$ isolated from $P$. pellucida leaves is an ursane-type triterpenoid.

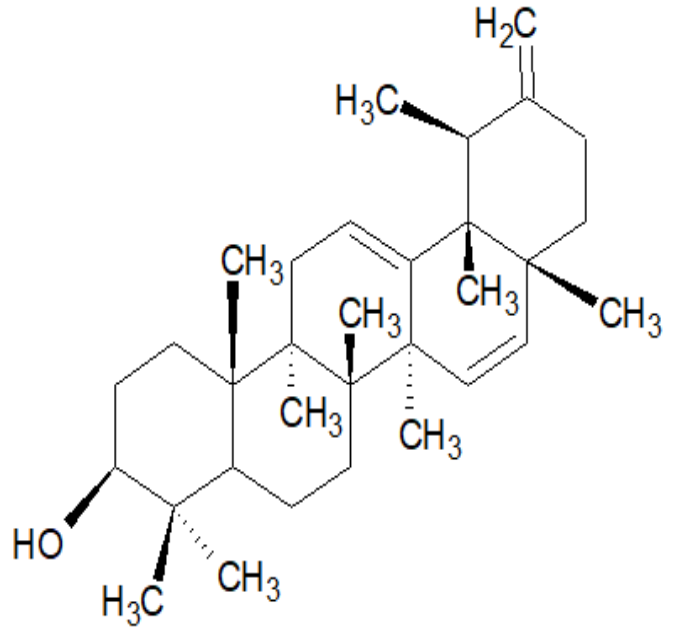

Fig 3. ursane - type triterpenoid
Conclusion: Peperomia pellucida leaves appears to be suitable for developing drugs that can be used to treat several diseases or disorders, this could be attributed to the ursane-type triterpenoid and other isolated bioactive compounds present in the leave. Utilization of this plant in suitable form can be beneficial in terms of promotion on health and disease therapy.

Acknowledgements: The authors are grateful to Mr I. K. Ndukwe of Forestry Department, Michael Okpara University of Agriculture, Umudike, for identifying and authenticating the plant sample. We are also grateful to Prof. John Igoli for his assistance to run spectral analysis on the sample at the University of Strathclyde, Glasgow, Scotland.

\section{REFERENCES}

Chukwuma, EC; Soladoye, MO; Feyisola, RT (2015). Traditional medicine and the future of medicinal plants in Nigeria. J Med Plants Stud. 3:23-29.

Coe, FG; Anderson GJ (1999). Ethnobotany of the sumu (Ulwa) of southeastern Nicaragua and comparisons with Miskitu plant lore. Econ Bot, $53: 363-86$

Das, NJ; Saikia, SP; Sarkar, S; Devi, K (2006). Medicinal plants of North Kamrup district of Assam used in primary healthcare system. Indian $J$ Tradit Know, 5:489-93.

Hayat, M; Ansari, S; Ali, M; Navad, T; Bhat, Z (2005). New Ursane-Type Triterpenes from Zizyphus vulgaris roots. Pharm. Biol. 43(5): 392-395.

Humzah, RU; Odetola, AA; Erukainure, OL; Oyagbemi, AA (2012). Peperomia pellucida in diets modulates hyperglyceamia, oxidative stress and dyslipidemia in diabetic rats. J. Acute Dis.1:135-40.

Kalita, GJ; Rout, S; Mishra, RK; Sarma, P (2015). Traditionally used medicinal plants of bajali subdivision, barpeta district, Assam. J. Med. Plants Stud. 3:8-17.

Khan, A; Rahman, M; Islam, S (2010). Isolation and bioactivity of a xanthone glycoside from peperomia pellucida. Life Sci. and Med. Res., Vol. 2010, LSMR-1.

Khan, MR; Omoloso, AD (2002). Antibacterial activity of Hygrophila stricta and Peperomia pellucida. Fitoterapia. 73(3): 251-254. 
Karunamoorthi, K; Jegajeevanram, K; Vijayalakshmi, J; Mengistie, E (2013). Traditional medicinal plants: a source of phytotherapeutic modality in resource - constrained health care settings. Evid.Based Complementary Altern. Med. 18(1): 67-74.

Manalo, JB; Han, BH; Han, YW; Park, MH; Anzald, FE (1983). Studies on the ether soluble neutral compounds of peperomia pellucida. Arch. Pharm. Res. 6(2):133-136.

Nwokocha, CR; Owu, DU; Kinlocke, K; Murray, JR; Thaxter, K; McCalla, G; Young, L (2012). Possible mechanism of action of the hypotensive effect of Peperomia pellucida and interactions between human cytochrome P450 enzymes. J. Med. Aromat. Plants, 1:105.

Pranab, G; Amitava, M; Mohammad, G (2012). A new bioactive ursane-type triterpenoid from Croton bonplandianum Bail. J Chem Sci. 125(2): 359-364.
Santos, MRA; Lima, MR; Oliveira, CL. (2014). Medicinal plants used in Rondônia, Western Amazon, Brazil. Rev Bras Plant Med 16 Suppl 1:707-20.

Waty, DR; Saputri, FC; Munim, A (2017). Secondary metabolites screening and acute toxicity test of Peperomia pellucida (L.) Kunth methanolic extracts. Int J PharmTech Res, 10:31-38.

Xu, S; Li, N; Ning, MM; Zhou, CH; Yang, QR; Wang, MW (2006). Bioactive compounds from Peperomia pellucida. J. Nat. Prod. 69(2): 247-250.

Yan-Li, Z; Wei-Sheng, F; Xiao-Ke, Z; Yan-Gang, C; Yan-Yan, L;Hui, C; Hai-Xue, K (2013). Three new ursane-type triterpenes from the leaves of Rehmannia glutinosa. Fitoterapia, 89: 15-19. 